\title{
MORTALITY RISK FACTORS IN TETRALOGY OF FALLOT PATIENTS UNDERGOING TOTAL CORRECTION
}

\author{
Juliana Juliana1, Yan Efrata Sembiring', Mahrus Abdur Rahman, Heroe Soebroto \\ ${ }^{1}$ Faculty of Medicine, Universitas Airlangga, Surabaya, Indonesia \\ 2 Department of Cardiothoracic and Vascular Surgery, Faculty of Medicine, Universitas Airlangga, Surabaya, \\ Indonesia/ Dr. Soetomo General Academic Hospital, Surabaya, Indonesia \\ ${ }^{3}$ Department of Pediatric, Faculty of Medicine, Universitas Airlangga, Surabaya, Indonesia
}

\begin{abstract}
Total correction has been used as the preferred treatment for Tetralogy of Fallot patients in every part of the world. However, the mortality in developing countries was as high as $6.9 \%$ to $15.3 \%$. This is a retrospective analytic study that analyze pre and post-operative risk factors that affect mortality on TOF patients that were performed total correction in Indonesia. A total of 47 TOF patients that were performed total correction from January 2016 to September 2019 were enrolled in this study based on the inclusion criteria. Preoperative and postoperative data were obtained from medical records. In this research, majority of mortality was found in male patients (39.3\%), while the female's rate was lower (36.8\%). Overall mortality was $38.3 \%$ and 1 operative death was found. The average age of patients was 84.12 months (12-210 months), whereas the average height (85.56 $\pm 36.17 \mathrm{~cm} v \mathrm{~s} 112.93 \pm 21.73)$ and weight $(17.22 \mathrm{~kg}$ vs $28.21 \mathrm{~kg})$ were lower for mortality patients. Some significant preoperative variables were identified as mortality risk factors such as: age below 60 months $(p=0.047)$, smaller weight and height $(p=0.008 ; p=0.002)$, abnormal hematocrit $(p=0.002)$, and oxygen saturation below $75 \%(p=0.018)$. Significant postoperative risk factors included: temperature above $38.5^{\circ} \mathrm{C}(p=0.000)$, and ventilator time more than 48 hours $(p=0.033)$. In conclusion, the mortality of TOF patients undergoing total correction in developing countries was quite high. It was associated with some risk factors including younger age, lower weight and height, low oxygen saturation, post-operative fever and prolonged ventilator time.
\end{abstract}

Keywords: tetralogy of Fallot; total correction; mortality; risk factors

\section{ABSTRAK}

Total koreksi adalah pengobatan pilihan untuk pasien Tetralogi of Fallot di berbagai negara. Namun, angka kematian di negara berkembang masih setinggi 6,9\% hingga 15,3\%. Penelitian ini adalah penelitian retrospektif analitik yang bertujuan untuk menganalisis faktor risiko pra dan pasca operasi yang mempengaruhi mortalitas pasien TOF yang dilakukan total koreksi di Indonesia. Sebanyak 47 pasien TOF yang dilakukan total koreksi sejak Januari 2016 hingga September 2019 dilibatkan dalam penelitian ini berdasarkan kriteria inklusi. Data pra operasi dan pasca operasi diperoleh dari rekam medis. Dalam penelitian ini, mayoritas kematian ditemukan pada pasien laki-laki (39,3\%) sedangkan pada perempuan lebih rendah (36,8\%). Kematian keseluruhan adalah 38,3\% dan 1 kematian operasi ditemukan. Usia rata-rata pasien adalah 84,12 bulan (12-210 bulan). Sedangkan rata-rata tinggi badan $(85.56 \pm 36.17 \mathrm{~cm} v \mathrm{~s} 112.93 \pm 21.73)$ dan berat badan $(17.22 \mathrm{~kg} v \mathrm{~s} 28.21 \mathrm{~kg})$ lebih rendah untuk pasien dengan mortalitas. Beberapa variabel signifikan sebelum operasi diidentifikasi sebagai faktor risiko kematian, seperti usia di bawah 60 bulan $(p=0,047)$, berat badan dan tinggi badan rendah $(p=0,008 ; p=0,002)$, hematokrit abnormal $(p=0,002)$, dan saturasi oksigen di bawah $75 \%(p=0,018)$. Faktor risiko pasca operasi yang signifikan meliputi suhu di atas $38,5^{\circ} \mathrm{C}(p=0,000)$, dan waktu ventilator lebih dari 48 jam $(p=0,033)$. Kesimpulannya, angka kematian pasien TOF yang menjalani koreksi total di negara berkembang cukup tinggi. Ini terkait dengan beberapa faktor risiko termasuk usia yang lebih muda, berat dan tinggi badan rendah, saturasi oksigen yang rendah, demam pasca operasi dan waktu ventilator yang lama.

Kata kunci: tetralogy of fallot; total koreksi; mortalitas; faktor risiko

Correspondence: Yan Efrata Sembiring, Department of Cardiothoracic and Vascular Surgery/Dr. Soetomo General Academic Hospital, Surabaya, East Java 60286. Email: yanefratas@yahoo.com

pISSN:2355-8393 • eISSN: 2599-056x • doi: 10.20473/fmi.v57i2.22107

- Fol Med Indones. 2021;57:151-157 • Received 18 Sept 2020 • Accepted 03 Dec 2020

- Open access under CC-BY-NC-SA license • Available at https://e-journal.unair.ac.id/FMI/ 


\section{INTRODUCTION}

Tetralogy of Fallot is a congenital heart disease which involves interventricular communication with a ventricular septal defect (VSD), obstruction of the right ventricular outflow tract (RVOT), overriding of the ventricular septum by the aortic root, and also right ventricular hypertrophy $(\mathrm{RVH})$. The incidence of this malformation is quite rare, around 3 in every 10,000 live births, it is the most common cause of cyanotic heart disease in patients beyond the neonatal age and contributes for around $7-10 \%$ of all congenital heart disease (Bailliard \& Anderson 2009).

Total correction procedure for TOF has been performed for more than 40 years with the long-term outcome and quality of life have been considered excellent with only $3 \%$ mortality rate and more than $90 \%$ survival rate in 5 years (Atik 2004). The benefits of early repair are considered many, such as: reduce hypoxaemia duration and its negative sequelae, preserve myocardial function, stimulate angiogenesis in pulmonary vascular bed, and support lung growth (Heinisch et al 2019).

Despite all the benefits, some complications of varying severity occur almost invariably after TOF total repair that leads to remarkable morbidity or even mortality. Some of the most commonly found complication post total correction includes rebleeding, arhythmia, acute heart failure, respiratory failure, and even sudden death. Medical centers in developed countries made successful total corrections without premature death, while in developing countries the mortality rate was as high as $6.9 \%$ to $15.3 \%$ (Hashemzadeh 2010).

There are some factors used as predictors for the mortality and morbidity in TOF repair which can be divided into pre-operative and post-operative risk factors. Preoperative risk factors consist of the patients' age, gestational age, gender, weight, hypercyanotic spells, saturation, and comorbidities. Some postoperative risk factors are: length of ICU stay, duration of mechanical ventilation, duration of inotropic support, and postoperative complications (Egbe et al 2014).

This shows that despite total repair surgery has been used as a standard procedure for early repair in TOF patients, the morbidity and mortality should still be considered, especially in low-middle income countries. Therefore, this study analyzed pre and post-operative risk factors that contributed to the mortality of TOF patients performed total correction.

\section{MATERIALS AND METHODS}

This retrospective cross-sectional study was conducted in Dr. Soetomo General Academic Hospital, Surabaya, Indonesia. Total sampling was done from all medical records of TOF patients performed total correction from January 2016 to September 2019. Patients with history of minimally invasive pre-operative actions and incomplete medical record data were excluded. This study had been approved by Ethical Committee in Health Research at Dr. Soetomo General Academic Hospital Surabaya under a decree number 1280/KEPK/VII/2019.

The diagnosis of TOF was defined by ICD 10 diagnosis code 21.3 where only patients performed total correction were taken. Data of the pre and postoperative risk factors were obtained from medical records. Preoperative risk factors included age, weight, height, oxygen saturation, hypoxic spell history, BT-Shunt history, hematocrit and comorbidities, while postoperative risk factors included duration of ICU stay, temperature, complications and ventilator duration. Patient's body temperature was defined as the highest axilla temperature within the first 3 days of treatment in ICU. In addition, patient's ventilator duration was measured when patient entered the ICU after went through repair and measured in hours.

We also conducted statistical analysis performed using SPSS Statistics 17.0 computer program for windows. A normality test was performed using KolmogorovSmirnov test. Then, descriptive statistical analysis was performed in the form of mean $\pm \mathrm{SD}$ and median. To assess differences between groups the Mann-Whitney's test and Independent Sample T-Test were used for continuous data and Chi-Square or Fisher's exact test for categorical data. A p-value of $<0.05$ was considered statistically significant.

\section{RESULTS}

\section{Sample Characteristics}

From 2016 until September 2019, there were 66 TOF patients performed total correction in Dr. Soetomo General Academic Hospital, Surabaya. Fifteen missing medical records and four incomplete records were excluded, leaving only 47 medical records used as sample. Patients' age varied from 12 months to 306 months with an average of $84.12( \pm 65.69)$ months old. From 18 deceased patients, there were 11 male $(61.1 \%)$ and 7 females (38.9\%). The mean for weight and height in deceased patients were $17.22 \mathrm{~kg}$ and $85.56 \pm 36.17$ $\mathrm{cm}$. There were 11 deceased patients with intra and 
extra-cardiac comorbidities, including Patent Ductus Arteriosus (PDA), Arterial Septal Defect (ASD), Persistent Left Superior Vena Cava (PLSVC), Aortic Regurgitation (AR), Patent Foramen Ovale (PFO), and Major Aortopulmonary Collateral Arteries (MAPCAs), Bilateral Polycystic Kidney Disease (PKD), further comorbidities are explained on fig.1 and fig.2. Only 2 deceased patients had postoperative complications. One of them had acute kidney injury and the other had bleeding.

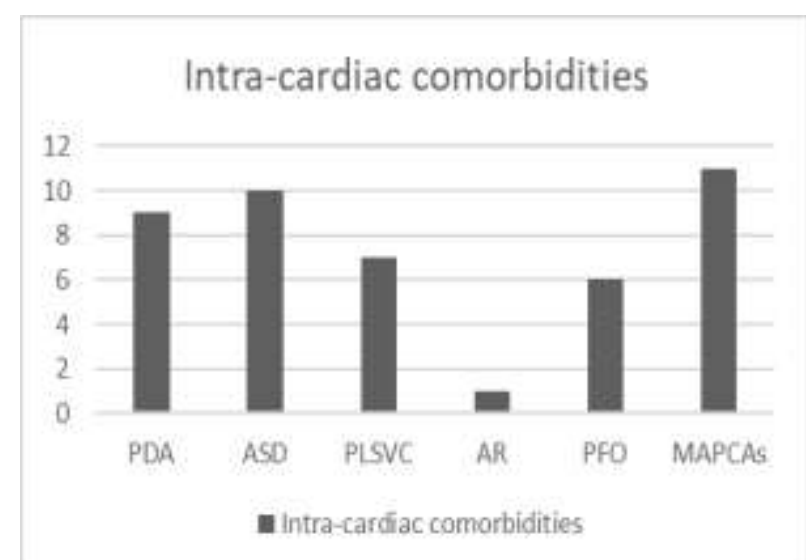

Figure 1. Intra-cardiac comorbid disease in patients with Tetralogy of Fallot

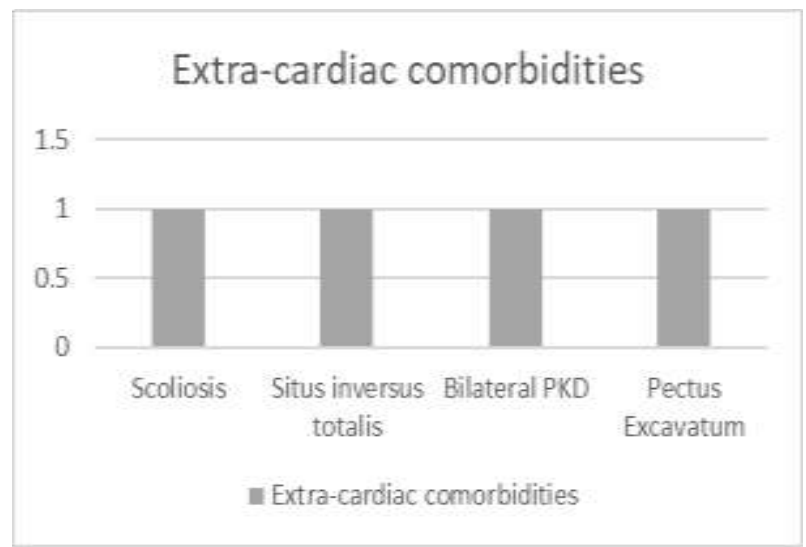

Figure 2. Extra-cardiac comorbid diseases in patients with Tetralogy of Fallot 
Table 1. Sample characteristics of Tetralogy of Fallot patients performed total correction

\begin{tabular}{|c|c|c|c|c|c|}
\hline Characteristics & $\begin{array}{l}\text { Deceased } \\
(\mathrm{n}=18)\end{array}$ & $\begin{array}{l}\text { Survivor } \\
(\mathrm{n}=29)\end{array}$ & p-value & $\begin{array}{l}\text { Contingency } \\
\text { Coefficient }\end{array}$ & Risk Estimate \\
\hline \multicolumn{6}{|l|}{ Sex } \\
\hline Male (\%) & $11(61.1)$ & $17(58.6)$ & \multirow[t]{2}{*}{-} & \multirow[t]{2}{*}{ - } & \multirow[t]{2}{*}{-} \\
\hline Female $(\%)$ & $7(38.9)$ & $12(41.4)$ & & & \\
\hline \multicolumn{6}{|l|}{ Age (months) } \\
\hline$<60$ & $13(72.2)$ & $11(37.9)$ & \multirow[b]{2}{*}{0.047} & \multirow[b]{2}{*}{$0.32(0.022)$} & \multirow[b]{2}{*}{2.5} \\
\hline$>60$ & $5(27.8)$ & $18(62.1)$ & & & \\
\hline Weight $(\mathrm{kg})$ & 17.22 & 28.21 & 0.008 & - & - \\
\hline Height (cm) & $85.56 \pm 36.17$ & $112.93 \pm 21.73$ & 0.002 & - & - \\
\hline \multicolumn{6}{|l|}{ Temperature $\left({ }^{\circ} \mathrm{C}\right)$} \\
\hline$<38.5$ & $4(22.2)$ & $26(89.6)$ & \multirow{2}{*}{0.000} & \multirow[b]{2}{*}{$0.57(0.000)$} & \multirow[b]{2}{*}{6.18} \\
\hline$\geq 38.5$ & $14(77.8)$ & $3(10.4)$ & & & \\
\hline \multicolumn{6}{|c|}{ Oxygen Saturation (\%) } \\
\hline$\leq 75$ & $9(50.0)$ & $4(13.8)$ & \multirow[b]{2}{*}{0.018} & \multirow[b]{2}{*}{$0.37(0.007)$} & \multirow[b]{2}{*}{2.6} \\
\hline$>75$ & $9(50.0)$ & $25(86.2)$ & & & \\
\hline \multicolumn{6}{|c|}{ Hematocrit Level (\%) } \\
\hline$>48$ & $16(88.9)$ & $11(57.9)$ & \multirow[b]{2}{*}{0.002} & \multirow[b]{2}{*}{$0.45(0.001)$} & \multirow[b]{2}{*}{5.9} \\
\hline$\leq 48$ & $2(11.1)$ & $8(42.1)$ & & & \\
\hline \multicolumn{6}{|l|}{ BT-shunt History } \\
\hline Yes & $3(16.7)$ & $3(10.3)$ & \multirow{2}{*}{0.856} & & \multirow[b]{2}{*}{ - } \\
\hline No & $15(83.3)$ & $26(89.7)$ & & - & \\
\hline \multicolumn{6}{|c|}{ Hypoxic Spell History } \\
\hline Yes & $4(22.2)$ & $7(24.1)$ & \multirow{2}{*}{1.000} & \multirow[b]{2}{*}{-} & \multirow[b]{2}{*}{-} \\
\hline No & $14(77.8)$ & $22(75.9)$ & & & \\
\hline \multicolumn{6}{|c|}{ Comorbid Disease } \\
\hline Yes & $11(61.1)$ & $15(51.7)$ & & & \\
\hline No & $7(38.9)$ & $14(48.3)$ & 0.743 & - & - \\
\hline Ventilator Durati & & & & & \\
\hline$\geq 48$ & $10(55.6)$ & $6(20.7)$ & & & \\
\hline$<48$ & $8(44.4)$ & $23(79.3)$ & 0.033 & $0.34(0.014)$ & 2.42 \\
\hline ICU Duration (h & & & & & \\
\hline$\geq 144$ & $8(44.4)$ & $7(24.1)$ & & & \\
\hline$<144$ & $10(55.6)$ & $22(75.9)$ & 0.259 & - & - \\
\hline Post Op Complic & & & & & \\
\hline Yes & $2(11.1)$ & $5(17.2)$ & 0879 & & \\
\hline No & $16(88.9)$ & $24(82.8)$ & 0.879 & - & - \\
\hline
\end{tabular}

\section{Preoperative Variables}

It was found that the average weight of deceased patients was $17.22 \mathrm{~kg}$ and it significantly affected the mortality $(\mathrm{p}=0.008)$. In addition, patients with lower height was also significant as a risk factor to mortality with p-value 0.002 .
Patients with age below 60 months was identified as significant risk factor for mortality $(\mathrm{p}<0.05)$ as high as 2.5 times higher than older age. Low oxygen saturation $(\leq 75 \%)$ was also identified as a significant risk factors $(\mathrm{p}<0.05)$ with risk estimation as high as 2.6 times. Patients with abnormal hematocrit level $(>48 \%)$ also increased mortality risk 5.9 times higher $(\mathrm{p}<0.05)$. On 
the other hand, hypoxic spell, BT-shunt history, and comorbidities were not a significant risk factor. Further Pre-operative data were shown in Table 1.

\section{Postoperative Variables}

Postoperative complications found in this study include bleeding, central hypothyroid, pleural effusion, RV dysfunction, septic, and acute kidney injury. There were only 2 deceased patients with postoperative complications which were due to bleeding and acute kidney injury. Complications and ICU stay were not significant as a mortality risk factors $(p>0.05)$. This study categorized temperature into two groups; those with fever $\left(\geq 38.5^{\circ} \mathrm{C}\right)$ and without fever $\left(<38.5^{\circ} \mathrm{C}\right)$. Postoperative fever was identified as a significant risk factor $(p<0.01)$ with the risk estimation as high as 6.18 times higher than patients without fever. The average ventilator time in this study was 51 hours. Prolong ventilator time $(\geq 48 \mathrm{~h})$ increased the risk for mortality 2.42 times higher than patients without prolonged used of ventilator. Further post-operative data were shown in Table 1.

\section{DISCUSSION}

In this study, the prevalence of TOF that was performed total correction was higher in male $(59.6 \%)$ than female $(40.4 \%)$. The overall mortality in our study is $38.3 \%$. Additionally, the mortality was also higher in male rather than female patients with $39.3 \%$ and $36.8 \%$ respectively. Previous studies also showed that TOF prevalence and mortality was higher in male than female (Pradipto et al 2017).

The optimum age of performing total correction is between ages 3 to 11 months. However, in low-income country, most patients were performed surgery after 12 months of life. Contrary to the practice in developed countries, patients in developing countries tend to not receive timely repair intervention. Less than $50 \%$ of the population has access to health care facilities and the likelihood of receiving earlier corrective surgery is extremely low (Heinish et al 2019)._A study showed that in developing countries, age was not a risk factor for death unlike in developed countries (Sandoval et al 2018). In this study, younger age was significant as risk factor for mortality. However, the imbalance distribution of age from 12 months to 306 months and also the comorbidities in younger patients should be considered as it might complicate the disease more.

In this study, lower weight and height were identified as risk factors for mortality. In contrast, a research held in developing countries stated that patients' weight/body mass index for age below the fifth percentile becomes the risk factor for death after initial primary repair (Sandoval et al 2018). Being underweight at the time of pediatric cardiac surgery has been shown to be a risk factor for death (Rossano et al 2007).

The increase of preoperative hematocrit was associated with postoperative blood loss as it might alter the platelet function (Guevara et al 2017). In this study, patients' hematocrit was grouped into normal $(\leq 48 \%)$ and abnormal (>48\%). The average hematocrit level was $52.3 \%$ and was significant as mortality risk factor as it increases risk 5.9 times higher.

Hypercyanotic spell or Tet spell is a characteristic in TOF patients by sudden and striking decrease in saturation of oxygen due to obstruction of subpulmonary outflow tract. A hypercyanotic spell will usually reach its peak on age of 2 to 3 months and indicate immediate repair (Bailliard \& Anderson 2009). In recent study, it was stated that hypoxic spell was the most frequent cause of mortality for TOF patients without surgical intervention (Diaz \& Guillaume 2020). In this study, hypercyanotic spell was not a risk factor for mortality with only 4 patients were deceased. As in the low-middle income countries, most patients were unlikely to get treatment during young age.

Other than total correction for TOF patients, a palliative treatment such as BT shunt is also frequently performed. However, in this study, most patients who were performed total correction did not have history of palliative treatment, as there were only 3 mortality found. Other studies also supported that previous palliative treatment did not influence the outcome of primary repair, where there was only one death found in patients who had sudden cardiac death (Touati et al 1990).

This study showed that comorbid diseases in patients were not significant as mortality risk factor, in accordance to previous researches that found no correlation between comorbid anomalies and mortality (Cobanoglu \& Schultz 2002). Meanwhile, other studies that include extreme forms of TOF with pulmonary atresia and absent pulmonary valve syndrome showed a high mortality risk factors compared to our study (Mohan et al 1995, Touati et al 1990). This might be caused of the anatomy complexity of the population that significantly affected the mortality.

This study found out that oxygen saturation was a significant risk factor to mortality. Patients with low oxygen saturation tend to have 2.6 times higher risk for mortality compare to those with higher saturation. Other study mentioned that poor pre-operative oxygenation was one of the most significant factors that affect early 
mortality in TOF repair (Saygi et al 2015). In contrast, other study found no significant difference for low oxygen saturation to the prolonged of ICU stay and ventilator duration, that might interfere with the late complications and increased the mortality risk (Egbe et al 2014).

We had found that prolonged ventilator time $(\geq 48$ hours) increased mortality as high as 2.42 times. Some studies also showed a significant correlation of ventilator duration to mortality in early repair TOF patients, which can be caused by pulmonary valve annular hypoplasia or ventilator-associated pneumonia (VAP) (Egbe et al 2014, Li et al 2014).

At the same time, the morbidity of TOF is commonly related to the ICU morbidity after the primary repair. We classified the length of ICU stay into two group of those with prolonged stay $(\geq 144$ hours) and those without prolonged time $(<144)$. The mean duration of ICU stay is 115 hours with the longest stay was 912 hours and the shortest time was 2 hours. Unlike most study that usually showed significant effect of duration of ICU stay to mortality (Egbe et al 2014, Yang et al 2019). This study showed that prolonged ICU stay was not an independent factor for mortality. Thus, it could be concluded that the length of ICU stay might be a risk factor to mortality but not solely.

Despite of the early outcomes of total repair in TOF patients have improved since the first time it was introduced in 1950s, the late outcomes of early repair remain uncertain. Late complications are determined by patients age when performed total correction, where most patients after the age of one year will result in good outcomes (Waqar et al 2017). In our study, late complications was not identified as risk factor for mortality, as most repair were performed after the age of one year. We could not include early complications, because data were not stated in medical records. A different result might happen in other studies in which early complications were included. Residual ventricular septal defect, pulmonary stenosis and pulmonary regurgitation might also affect the result as well.

Post-operative fever is a situation when the body temperature is greater than $38^{\circ} \mathrm{C}$ on 2 consecutive postoperative days or greater than $39^{\circ} \mathrm{C}$ on any postoperative day. Fever as the manifestation of sepsis should be promptly managed to lower the mortality rates (Abdelmaseeh et al 2019). Most fever that develops within 48 hours after surgery are benign and self-limiting. Fever that develops after the first 48 hours is more likely to have an infectious cause. However, the non-infectious causes must also be considered. The post-operative fever might be associated with metabolic response to trauma, systemic response to the cardiopulmonary bypass, hypothermia, presence of drainage tubes, drugs, blood transfusion, or infections. Therefore, it needed more attention as it might cause further complications that will eventually lead to mortality (Gupta et al 2012).

The frequency of post-operative fever was reported as high as $46 \%$, with $56 \%$ cases appeared within 24 hours after surgery and $70 \%$ cases of remission within 72 hours. It is stated that fever was more common to develop in patients who underwent open-heart surgery rather than the closed one (Villasis et al 2002). In this study, 17 patients developed post-operative fever and 14 of them were deceased. Post-operative fever contributes to the mortality with the risk estimation is 6 times higher compare to those without fever.

\section{Strength and Limitations of the study}

To our knowledge, this was the first study that analyzed pre and postoperative rick factors mortality of TOF performed total correction in Indonesia. However, this study might not yet to be generalized since it only involved single-center as the source of data. This was also a retrospective study that used consecutive samplings from all patients who were admitted for TOF diagnosis and performed total correction. Hence, selection bias might occur. Secondly, the low incidence of complications, small number of patients with significant ICU morbidity, and also incomplete data in medical records could have affected accuracy of analysis for potential predictors of morbidity. Additionally, there were other variables associated with perioperative management, physician care giver and surgical expertise (different surgeons performed the operation) could have an impact on the outcomes.

\section{CONCLUSION}

The mortality of TOF patients undergoing total correction in developing country, especially Indonesia was still high. There were some preoperative and postoperative risk factors that affected the mortality in TOF patients performed total correction which included age below 60 months, lower weight and height, oxygen saturation below $75 \%$, postoperative fever $\left(\geq 38.5^{\circ} \mathrm{C}\right)$, and prolonged ventilator time $(\geq 48 \mathrm{~h})$. However, some factors such as history of hypoxic spell, previous palliative treatment, comorbidities, post-operative complication and prolong ICU stay did not appear to affect mortality independently. 


\section{REFERENCES}

Abdelmaseeh TA, Azmat CE, Oliver TI (2019). Postoperative fever. In: StatPearls. Treasure island (FL), StatPearls Publishing, p 1.

Atik F (2004). Long-term results of correction of tetralogy of Fallot in adulthood. Eur $\mathrm{J}$ Cardiothorac Surg 25, 250-255.

Bailliard F, Anderson R (2009). Tetralogy of Fallot. Orphanet J Rare Dis 4, 1-10.

Cobanoglu A, Schultz J (2002). Total correction of tetralogy of Fallot in the first year of life: late results. Ann Thorac Surg 74, 133-138.

Diaz-Frias J, Guillaume M (2020). Tetralogy of Fallot. In: StatPearls. Treasure Island (FL), StatPearls Publishing, p 22.

Egbe A, Mittnacht A, Nguyen K, et al (2014). Risk factors for morbidity in infants undergoing tetralogy of fallot repair. Ann Pediatr Cardiol 7, 13-8.

Guevara JH, Zorrilla-Vaca A, Silva-Gordillo GC (2017). The utility of preoperative level of erythrocytosis in the prediction of postoperative blood loss and 30-day mortality in patients with tetralogy of fallot. Ann Card Anaesth 20, 188-192.

Gupta A, Singh V, Varma A (2012). Approach to postoperative fever in pediatric cardiac patients. Ann Pediatr Cardiol 5, 61-68.

Hashemzadeh K, Hashemzadeh S (2010). Early and late results of total correction of tetralogy of Fallot. Acta Med Iranica 48, 117- 122

Heinisch PP, Guarino L, Hutter D, et al (2019). Late correction of tetralogy of Fallot in children. Swiss Med Wkly 149, 1-10.

Li S, Zhang Y, Li S et al. (2014). Risk factors associated with prolonged mechanical ventilation after corrective surgery for tetralogy of Fallot. Congenit Heart Dis 10, 254-262.
Mohan RV, Liddicoat J, McElhinney D, et al. (1995). Routine primary repair of tetralogy of Fallot in neonates and infants less than three months of Age. Ann Thorac Surg 60, S592-S596.

Pradipto S, Rahmat B, Purba S, et al. (2017). Early outcomes of tetralogy of Fallot repair: A 5-year experience at a Single Center. Jakarta, Department of Pediatric and Congenital Heart Surgery, National Cardiovascular Center-Harapan Kita.

Rossano J, Grenier M, Dreyer W et al. (2007). Effect of body mass index on outcome in pediatric heart transplant patients. J Heart Lung Transpl 26, S242S243.

Sandoval N, Carreño M, Novick W et al. (2018). Tetralogy of Fallot repair in developing countries: International quality improvement collaborative. Ann Thorac Surg 106, 1446-1451.

Saygi M, Ergul Y, Tola H et al. (2015). Factors affecting perioperative mortality in tetralogy of Fallot. Pediatr Int 57, 832-839.

Touati GD, Vouhé PR, Amodeo A, et al. (1990). Primary repair of tetralogy of Fallot in infancy. $\mathrm{J}$ Thorac Cardiovasc Surg 99, 396- 403.

Villasís-Keever MA, Zapata-Arenas DM, PenagosPaniagua MJ (2002). Frequency of postoperative fever in children with congenital heart disease undergoing cardiovascular surgery and associated risk factors. Rev Esp Cardiol 55, 1063- 1069.

Waqar T, Riaz M, Mahar T (2017). Tetralogy of Fallot repair in patients presenting after Infancy: A single surgeon experience. Pak J Med Sci 33, 984-987

Yang S, Wen L, Tao S, et al. (2019). Impact of timing on in-patient outcomes of complete repair of tetralogy of Fallot in infancy: An analysis of the United States National Inpatient 2005-2011 database. BMC Cardiovasc Disord 19, 1-8. 